\title{
Chemical constituents, cytotoxic activities and traditional uses of Micromelum minutum (Rutaceae): a review
}

\begin{abstract}
Micromelum minutum belongs to the family of aromatic deciduous trees and shrubs, Rutaceae. Different types of coumarins together with two alkaloids are found in the plant. Chemical constituents are isolate from different parts of the plant- leaves, stem, stem bark, fruits, seeds and roots. Traditionally, the plant is used for various purposes. Scientific investigations particularly focused on the cytotoxicity of the plant. The reviews compile the botanical description, traditional use, chemical constituents and cytitoxic activities of Micromelum minutum.
\end{abstract}

Keywords: Micromelum minutum, Rutaceae, coumarins, alkaloids, botanical description, traditional use, chemical constituents, cytotoxic activities
Volume 7 Issue 5 - 2019

\author{
Fatema-Tuz-Zohora, Choudhury Mahmood \\ Hasan, Monira Ahsan \\ Department of Pharmaceutical Chemistry, Faculty of Pharmacy, \\ University of Dhaka, Bangladesh
}

Correspondence: Fatema Zohora, Department of Pharmaceutical Chemistry, Faculty of Pharmacy, University of Dhaka, Bangladesh, Tel 01675338774 , Email fatema.zohora4l@gmail.com

Received: July 13, 2019 | Published: September 26, 2019

\section{Introduction}

Rutaceae, the rue family, composed of 160 genera and about 2,070 species of woody shrubs and trees and is distributed in warm temperate and tropical regions. ${ }^{1}$ The members of Rutaceae family have been used in perfumery, gastronomy, and traditional medicine and several publications have reported the presence of secondary chemical constituents. ${ }^{2}$ Phytochemical survey of this family reveals alkaloids, coumarins, flavonoids, limonoids, and volatile oils ${ }^{3}$ and these have been associated to different biological activities, for example, antimicrobial ${ }^{4}$ antidiarrhoeal, ${ }^{5}$ anticholinesterasic, ${ }^{6}$ antileishmanial, ${ }^{7}$ antiprotozoal, ${ }^{8}$ larvicidal, ${ }^{9}$ and antioxidant activities. ${ }^{10}$

There are seven subfamilies in the Rutaceae family, Aurantioideae is one of them. ${ }^{11}$ Clauseneae is one of the two tribes of Aurantioideae subfamily and Micromelum is the only genus of the subtribe Micromelinae. Coumarins, alkaloids, and flavonoids have been isolated from the Micromelum genus. ${ }^{12}$ The species of the Micromelum genus are small spineless trees and the species Micromelum minutum (synonym: Micromelum pubescens) is locally known as "Chemomar", "Cherek-cherek", "Secherek" or "Kematu" in Malayasia, ${ }^{13,14}$ The species has revealed a range of physiologically active compounds including anticoagulants, anti-carcinogens and anti-bacterials ${ }^{15-17}$ in it. The present review aims to compile up to date documentations of various phytochemical compositions and biological properties of Micromelum minutum.

\section{Traditional use}

Micromelum minutum is used in ringworm and ague, in the regulation of menstruation and the treatment of fever. ${ }^{17,18}$ It also used in traditional Thai medicine for tumor. ${ }^{19}$ The leaves are used traditionally as a febrifuge, the stems as a carminative, and the flowers and fruits as an expectorant and a purgative, respectively. ${ }^{20}$ The juice from the leaves is used to treat white scum on tongue, bad breath, haemorrhoids and to treat toothache and teething problems in babies. Leaves are also taken as a general tonic and shoots are used as a medicine treating infantile convulsions. The pounded leaves are an ingredient of a poultice used to relieve skin irritation. The leaves are rubbed on the skin to relieve irritations caused by scabies. The leaves or inner bark of the twigs are used in various ways to remedy headache and stomach-ache, to cure coughs and a sore tongue, to arrest profuse menstruation, to treat gonorrhoea, and as a remedy for thrush. Fluid from the bark is used to treat headaches and an infusion of the bark is ingested to cure stomachache..$^{21}$ Roots are used as a febrifuge, in decoction or infusions are given for diarrhoea in children, and as a carminative. They are considered to be useful for easing toothache and are also used as a remedy for stomach-ache and headache. Pieces of the root are chewed with betel for coughs. The plant is also used to cure headache. ${ }^{21}$

\section{Phytochemical constituents}

Previous phytochemical investigations on the different parts of Micromelum minutum have showed the presence of coumarins, triterpenes, alkaloids and phenylpropanoids (Table 1). ${ }^{13-15,22-24}$ An acetone extract of stems of the plant was chromatographed on silicagel, eluting with hexane-acetone, followed by repeated preparative TLC to afford six new coumarins along with six known ones. ${ }^{22}$ Two new monoterpene coumarins, minutin $\mathrm{A}$ and minutin $\mathrm{B}$, together with four known coumarins, 8,4"-dihydroxy-3",4"-dihydrocapnolactone2',3'-diol; 8-hydroxyisocapnolactone-2',3'-diol; 8-hydroxy-3",4"dihydrocapnolactone-2', $3^{\prime}$-diol and clauslactone $\mathrm{E}$ were purified..$^{25}$ Micromelum minutum seeds are rich source of coumarins. ${ }^{14}$ Lekphrom et al., ${ }^{26}$ isolated a new 7-oxygenated coumarin, 7-demethylmurralonginol isovalerate, and a new natural product, murralonginol, together with seven known 7-oxygenated coumarins, murralonginol isovalerate, murralongin, micromelin, scopoletin, microminutin, murrangatin, and minumicrolin. A new coumarin, with eleven known coumarins, murralonginol isovalerate, osthol, phebalosin, micromelin, murrangatin acetate, osthenon, murrangatin, minumicrolin, murralongin, umbelliferone and murracarpin, was isolated (Table 1). ${ }^{27}$ 
Table I Chemical constituents found in Micromelum minutum

\begin{tabular}{|c|c|}
\hline Plant part & Compound \\
\hline & Micromarin-A \\
\hline & Micromarin-B \\
\hline & Micromarin-C \\
\hline & Micromarin-F \\
\hline & Micromarin-G \\
\hline \multirow{9}{*}{ Stem } & Micromarin- $\mathrm{H}$ \\
\hline & \\
\hline & Micromelin \\
\hline & Murralonginol isovalerate \\
\hline & Microminutinin \\
\hline & 6-methoxymicrominutinin \\
\hline & Microminutin \\
\hline & Murrangatin \\
\hline & Phebalosin \\
\hline \multirow[t]{10}{*}{ Stem Bark } & Micromelin \\
\hline & Micropubescin \\
\hline & Microminutin \\
\hline & Flindersine \\
\hline & 3,4-dihydrocapnolactone \\
\hline & 2,3-epoxyisocapnolactone \\
\hline & 8-hydroxyisocapnolactone-2,3-diol \\
\hline & 8-hydroxy-3,4-dihydrocapnolactone-2,3-diol \\
\hline & 8,4-dihydroxy-3,4-dihydrocapnolactone-2,3-diol \\
\hline & 8-methoxycapnolactone \\
\hline \multirow[t]{8}{*}{ Leaves } & \\
\hline & Stigmasterol \\
\hline & 5(6)-gluten-3-one \\
\hline & $5(6)$ - gluten-3--ol \\
\hline & $\begin{array}{l}\text { 3, I I-dihydro-3,5-dimethyl-3-(4-methyl-3- } \\
\text { pentenyl)-pyrano[3,2-a]carbazol-9-ol (known as } \\
\text { mahanine) }\end{array}$ \\
\hline & Minutin A \\
\hline & Minutin B \\
\hline & Clauslactone $\mathrm{E}$ \\
\hline
\end{tabular}

Table continued

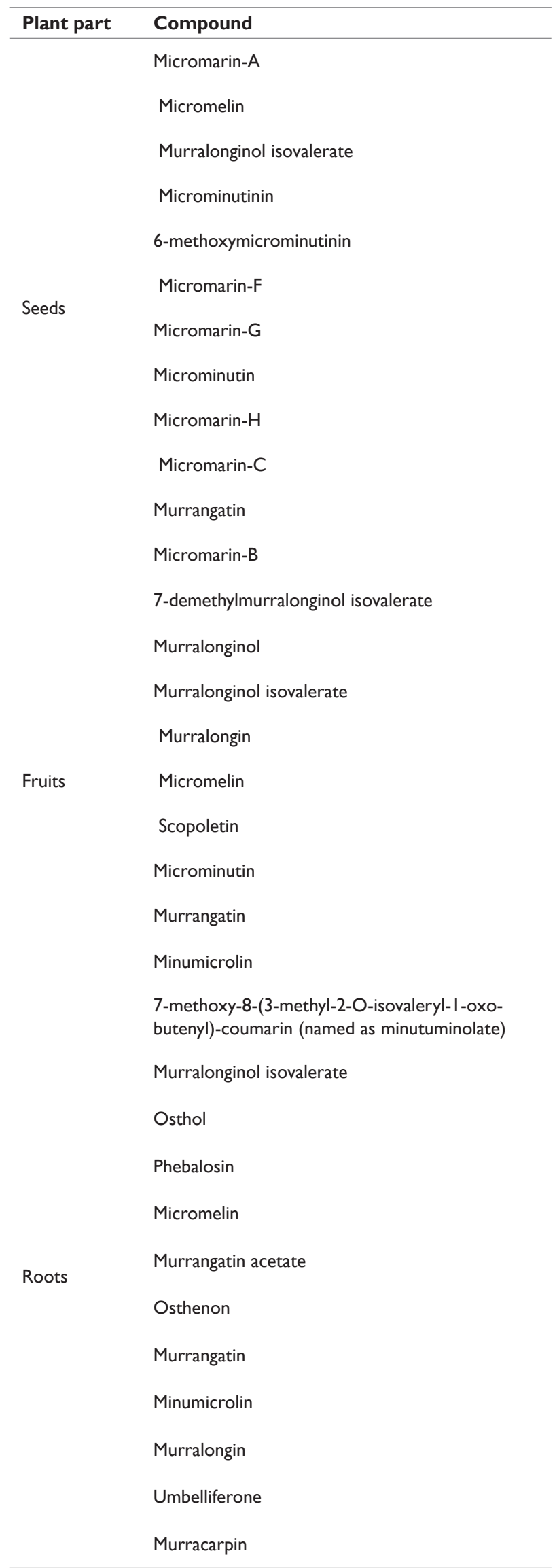




\section{(2,3-epoxyisocapnolactone}

5(6)- gluten-3 $\alpha$-ol

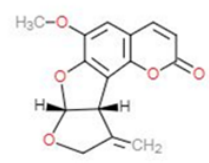

6-methoxymicrominutinin

OH

7-demethylmurralonginol isovalerate

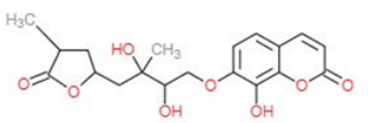

8.4-dihydroxy-3,4-dihydrocapnolactone-2,3-diol

8-hydroxy-3,4-dihydrocapnolactone-2,3-diol

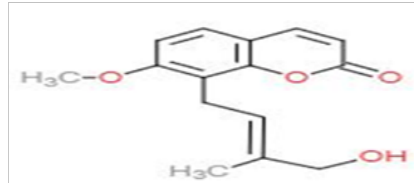

Micromarin-F

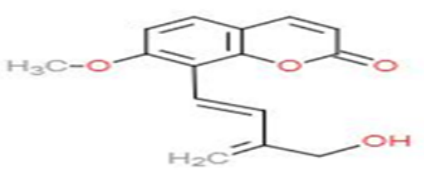

Micromarin-H

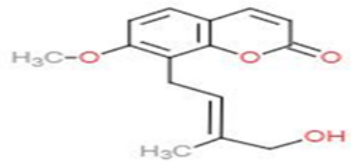

Micromarin-G

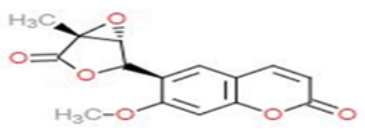

Micromelin

(NO-OCOH

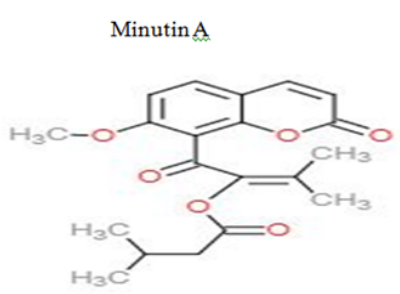

Minutuminolate
Minutin B

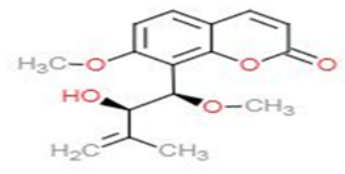

Murracarpin

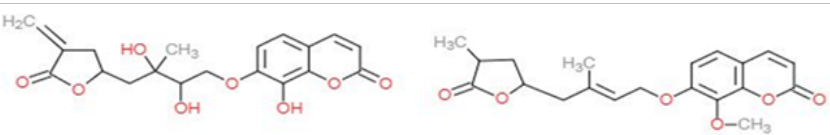

8-hydroxyisocapnolactone-2,3-diol 8-methoxycapnolactone

$$
\text { Clauslactone } \mathrm{E}
$$

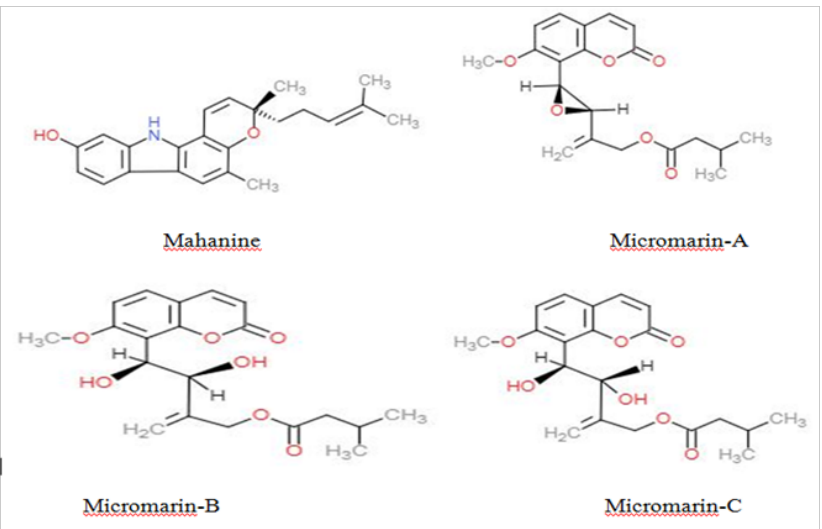

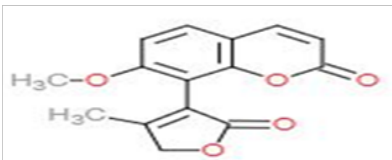

Microminutin

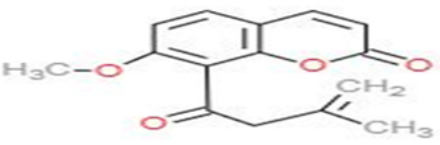

Micropubescin
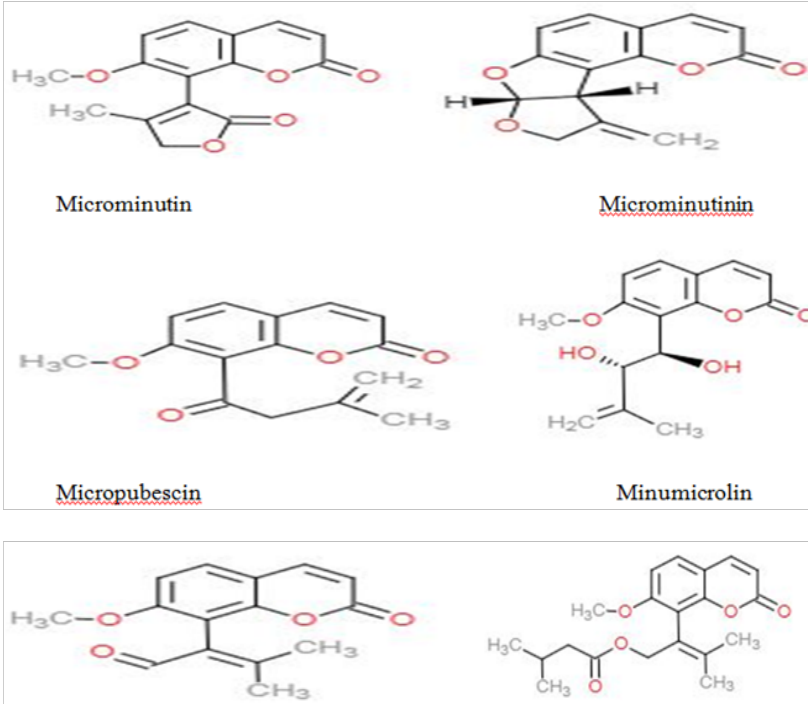

Murralongin

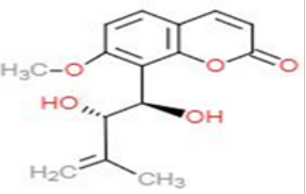

事

Murralonginol
Murralonginol isovalerate<smiles>COc1ccc2ccc(=O)oc2c1[C@H](O)[C@H](OC(C)=O)C(C)=O</smiles>

Murrangatin acetate 

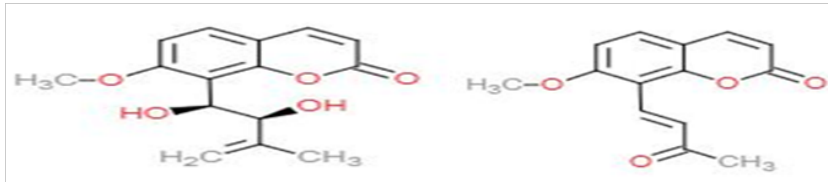

Murrangatin

Osthenon
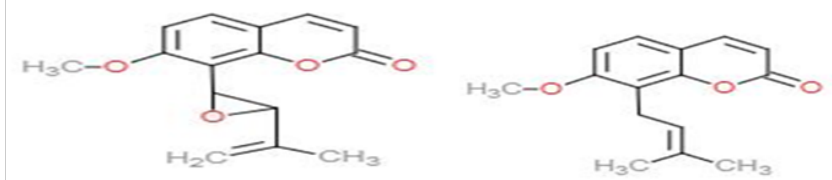

Phebalosin

Osthol

\section{Cytotoxic activities}

Micromelum minutum has been mainly investigated for its cytotoxic activities which are compiled in the following passages.

\section{CEM-SS cell line (T-lymphoblastic leukemia cells)}

The chloroform extracts of the leaves of Micromelum minutum showed strong activity, while the bark extracts had a moderate activity with $\mathrm{IC}_{50}$ values of 4.2 and $13.7 \mu \mathrm{g} / \mathrm{ml}$, respectively against a T-lymphoblastic leukemia (CEM-SS) cell line. ${ }^{28}$

Tan et al., ${ }^{29}$ investigated the induction of apoptosis by 2', 3'- epoxyisocapnolactone and 8-hydroxyisocapnolactone-2', 3'-diol which were previously isolated from the leaves of Micromelum minutum on CEM-SS cells. The inhibition effect of 2', 3'-epoxyisocapnolactone and 8-hydroxyisocapnolactone-2', 3'-diol at $50 \%$ of cell population $\left(\mathrm{IC}_{50}\right)$ was found to be $4.6 \mu \mathrm{g} / \mathrm{ml}(13.5 \mu \mathrm{M})$ and $3 \mu \mathrm{g} / \mathrm{ml}(7.8 \mu \mathrm{M})$ on CEM-SS cells, respectively. The induction time for apoptosis by 8-hydroxyisocapnolactone-2', 3'-diol in CEMSS was earlier than 2', 3'-epoxyisocapnolactone, which was $4 \mathrm{~h}$ and $12 \mathrm{~h}$ after treatment. This study has effectively demonstrated that 2', 3'-epoxyisocapnolactone and 8-hydroxyisocapnolactone-2', 3'-diol have a good potential as anti-cancer drug.

\section{U937 cell line (myeloid leukemia cells)}

Roy et al., ${ }^{31}$ investigated the effect of mahanine, a major constituent of the edible parts of the Thai vegetable Micromelum minutum, on the activation of the apoptotic pathway in human leukemia U937 cells. The study declares mahanine inhibits cell growth and induces apoptosis in U937 cells through a mitochondrial dependent pathway. In the study, various end points were used to screen for apoptosis: morphological changes in cells, the relative numbers of viable and apoptotic cells; translocation of membrane bound phosphatidylserine and DNA analysis. It was found that mahanine-induced apoptosis in U937 cells involved activation of caspases, including caspase-3, release of cytochrome $c$ into cytosol, loss of mitochondrial membrane permeability, and decreased levels of cellular ATP. As mitochondrial permeability is known to be important in the regulation of cytochromec release, observations in the study indicated that mitochondria were the principal target of mahanine. So more specificallythe study proposed that mahanine causes the mitochondrial membranes to lose their permeability, resulting in caspase- 3 activation and apoptosis. Estimated $\mathrm{IC}_{50}$ value of mahanine was $8.7 \mu \mathrm{M}$ at $12 \mathrm{~h}$ for apoptosis. ${ }^{31}$

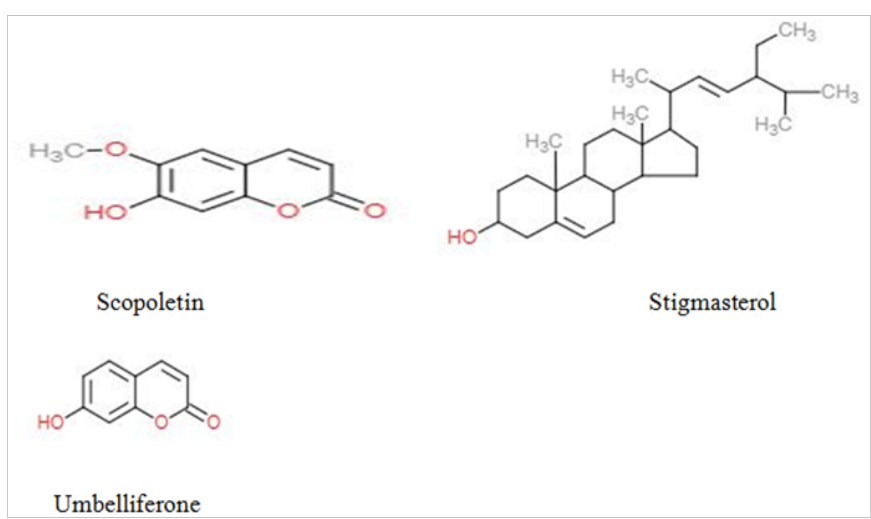

\section{KKU-I 00 cell line (cholangiocarcinoma cells)}

Cytotoxic assay against cholangiocarcinoma (KKU-100) cell line was performed employing the colorimetric method as described by Skehan and co-workers. ${ }^{33}$ Murralonginol, murralongin, micromelin, scopoletin, microminutin, murrangatin, and minumicrolin isolated from the fruits of Micromelum minutum exhibited cytotoxicity against cholangiocarcinoma cell line, KKU-100 and among these compounds microminutin and murrangatin showed strong cytotoxicity against the cholangiocacinoma (KKU-100) cell line (respective $\mathrm{IC}_{50}$ values of 1.7 and $2.9 \mu \mathrm{g} / \mathrm{mL}) .{ }^{34} \mathrm{The} \mathrm{IC}_{50}$ values of other compounds were $10.0 \mu \mathrm{g} / \mathrm{mL}$ (murralonginol), $9.0 \mu \mathrm{g} / \mathrm{mL}$ (murralongin), $9.2 \mu \mathrm{g} / \mathrm{mL}$ (micromelin), $19.2 \mu \mathrm{g} / \mathrm{mL}$ (scopoletin) and $10.2 \mu \mathrm{g} / \mathrm{mL}$ (minumicrolin). ${ }^{34}$

\section{HL60 cell line (promyelocytic leukemia cells)}

Two of the compounds, 2', 3'-epoxyisocapnolactone and 8-hydroxyisocapnolactone-2', 3'-diol isolated from the chloroform extract of the leaves of Micromelum minutum were significantly toxic to HL60 cell lines. The $\mathrm{IC}_{50}$ value of 2', 3'-epoxyisocapnolactone against the cancer cell line was $4.2 \mu \mathrm{g} / \mathrm{ml}$ and the $\mathrm{IC}_{50}$ value of 8-hydroxyisocapnolactone-2', 3'-diol was $2.5 \mu \mathrm{g} / \mathrm{ml}^{35}$

\section{HeLa cell line (cervical cancer cells)}

8-hydroxyisocapnolactone-2,3 -diol isolated from the chloroform extract of the leaves of Micromelum minutum showed strong cytotoxicity towards cervical cancer (HeLa) cell line with the value of $\mathrm{IC}_{50}$ was $6.9 \mu \mathrm{g} / \mathrm{ml}^{35}$

\section{HepG2 cell line (liver cancer cells)}

8-hydroxyisocapnolactone-2,3-diol isolated from the chloroform extract of the leaves of Micromelum minutum showed strong cytotoxicity towards liver cancer (HepG2) cell line with the value of $\mathrm{IC}_{50}$ was $5.9 \mu \mathrm{g} / \mathrm{ml}^{35}$

\section{SBC3 and A549 cell lines (lung adenocarcinoma cells)}

The cytotoxic activity against lung adenocarcinoma (SBC3 and A549) cell lines was determined by the MTT colorimetric cell viability assay. ${ }^{36}$ It showed Clauslactone E, minutin B and 8-hydroxyisocapnolactone-2,3 -diol isolated from the leaves of Micromelum minutum possess strong cytotoxic activity against the lung adenocarcinoma (SBC3 and A549) cell lines with $\mathrm{IC}_{50}$ values of 3.7, $10.4 \mu \mathrm{M}$ for clauslactone $\mathrm{E} ; 9.6,17.5 \mu \mathrm{M}$ for minutin $\mathrm{B}$; and8.8, $10.1 \mu \mathrm{M}$ for 8 -hydroxyisocapnolactone-2,3-diol, respectively. ${ }^{36}$ 


\section{K562 and K562/ADM cell lines (leukaemia cells)}

The cytotoxic activity against the leukaemia (K562 and K562/ADM) cell lines was determined by the MTT colorimetric cell viability assay. ${ }^{43}$ It showed Clauslactone E, minutin B and 8-hydroxyisocapnolactone-2 ,3 -diol isolated from the leaves of Micromelum minutum possess strong cytotoxic activity against the leukaemia (K562 and K562/ADM) cell lines with $\mathrm{IC}_{50}$ values of 12.1, and $10.8 \mu \mathrm{M}$ for clauslactone $\mathrm{E} ; 8.7$ and $6.7 \mu \mathrm{M}$ for minutin $\mathrm{B}$; 16.9 , and $10.1 \mu \mathrm{M}$ for 8 -hydroxyisocapnolactone-2,3-diol, respectively. ${ }^{36}$

\section{Crown gall tumors}

Phebalosin, isoled from the stem bark of Micromelum minutum was significantly inhibitory on the development of crown gall tumors on potato discs ( $\sim 64 \%$ and $\sim 70 \%$ in two independent determinations) ${ }^{37}$

\section{KB cell line (human epidermoid carcinoma cells)}

Murralonginol isolated from the fruits of Micromelum minutum, which was the first time isolation of the product from any natural source, ${ }^{38}$ was found to be weakly cytotoxic against human epidermoid (KB) cell line with $\mathrm{IC}_{50}$ value of $17.8 \mu \mathrm{g} / \mathrm{mL}$. 7-demethylmurralonginol isovalerate and murralonginol isovalerate isolated from the fruits of Micromelum minutum were also weakly cytotoxic against the cell line with $\mathrm{IC}_{50}$ value of $41.1 \mu \mathrm{g} / \mathrm{mL}$ and $30.4 \mu \mathrm{g} / \mathrm{mL}$ respectively. ${ }^{38}$

\section{$\mathrm{NCl}-\mathrm{H} 187$ cell line (human small cell lung cancer cells)}

7-demethylmurralonginol isovalerate, murralonginol and murralonginol isovalerate isolated from the fruits of Micromelum minutum were weakly cytotoxic against the cell line with the $\mathrm{IC}_{50}$ value of $46.5 \mu \mathrm{g} / \mathrm{mL}, 27.1 \mu \mathrm{g} / \mathrm{mL}$ and $49.5 \mu \mathrm{g} / \mathrm{mL}$ respectively. ${ }^{38}$

\section{MCF-7 cell line (human breast cancer cells)}

7-demethylmurralonginol isovalerate, murralonginol and murralonginol isovalerate isolated from the fruits of Micromelum minutum were weakly cytotoxic against the cell line with the $\mathrm{IC}_{50}$ value of $24.3 \mu \mathrm{g} / \mathrm{mL}, 8.2 \mu \mathrm{g} / \mathrm{mL}$ and $25.4 \mu \mathrm{g} / \mathrm{mL}$ respectively. ${ }^{38}$ Cytotoxic assay against human breast cancer (MCF-7) cell line was performed employing the colorimetric method as described by Skehan and coworkers. ${ }^{39}$

\section{Leishmania major}

Evaluation of the leishmanicidal activity of the methanol extract of M. minutum leaves revealed that the crude extract at $100 \mu \mathrm{g} / \mathrm{mL}$ killed $68 \%$ of L. major. Among the compounds isolated from the leaves of Micromelum minutum, minutin A, minutin B, 8-hydroxyisocapnolactone-2',3'-diol and clauslactone E showed a significant cytotoxic activity against Leishmania major with $\mathrm{IC}_{50}$ values of $26.2,20.2,12.1$, and $9.8 \mu \mathrm{M}$, respectively (Table 2). ${ }^{36}$

Table 2 Cytotoxic activities of extracts and different constituents of Micromelum minutum

\begin{tabular}{|c|c|}
\hline $\begin{array}{l}\text { Plant extracts or } \\
\text { constituents }\end{array}$ & Cytotoxicity \\
\hline Chloroform extract of leaves & - Showed strong activity against T-lymphoblastic leukemia (CEM-SS) cell line with IC50 value of $4.2 \mu \mathrm{g} / \mathrm{ml}$. \\
\hline Methanol extract of leaves & - The crude extract at $100 \mu \mathrm{g} / \mathrm{mL}$ killed $68 \%$ of Leishmania major. \\
\hline \multirow[t]{2}{*}{ Chloroform extract of bark } & - Had a moderate activity with IC50 value of $13.7 \mu \mathrm{g} / \mathrm{ml}$ against T-lymphoblastic leukemia (CEM-SS) cell line. \\
\hline & Showed cytotoxicity against T-lymphoblastic leukemia (CEM-SS) cell line with IC50 value of $4.6 \mu g / \mathrm{ml}(13.5 \mu \mathrm{M})$. \\
\hline \multicolumn{2}{|l|}{ 2',3'-epoxyisocapnolactone } \\
\hline & -Was significantly toxic to HL60 cell lines (promyelocytic leukemia cells) with the IC50 value of $4.2 \mu \mathrm{g} / \mathrm{ml}$. \\
\hline & - Showed cytotoxicity against T-lymphoblastic leukemia (CEM-SS) cell line with IC50 value of $3 \mu g / m l ~(7.8 \mu \mathrm{M})$. \\
\hline & -Was significantly toxic to HL60 cell lines (promyelocytic leukemia cells) with the IC50 value of $2.5 \mu \mathrm{g} / \mathrm{ml}$. \\
\hline & - Showed strong cytotoxicity towards cervical cancer (HeLa) cell line with the value of IC50 was $6.9 \mu \mathrm{g} / \mathrm{ml}$. \\
\hline \multirow[t]{4}{*}{$\begin{array}{l}\text { 8-hydroxyisocapnolactone- } \\
\text { 2',3'-diol }\end{array}$} & 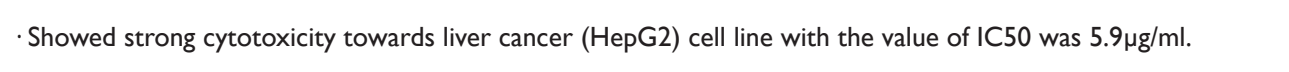 \\
\hline & $\begin{array}{l}\text { - Possesses strong cytotoxic activity against the lung adenocarcinoma (SBC3 and } \mathrm{A} 549 \text { ) cell lines with IC50 values } \\
\text { of } 8.8 \mu \mathrm{M} \text { and } 10.1 \mu \mathrm{M} \text { respectively. }\end{array}$ \\
\hline & $\begin{array}{l}\text { - Possesses strong cytotoxic activity against the leukaemia (K562 and K562/ADM) cell lines with IC50 values of } \\
16.9 \text {, and } 10.1 \mu \mathrm{M} \text { for K562 and K562/ADM cells respectively. }\end{array}$ \\
\hline & - Showed a significant cytotoxic activity against Leishmania major with IC50 values of I2.I $\mathrm{M}$. \\
\hline Mahanine & $\begin{array}{l}\text { - Inhibits cell growth and induces apoptosis in U937 (myeloid leukemia) cells through a mitochondrial dependent } \\
\text { pathway. Estimated IC50 value of mahanine was } 8.7 \mu \mathrm{M} \text { at } 12 \mathrm{~h} \text { for apoptosis. }\end{array}$ \\
\hline
\end{tabular}


Table continued

\section{Plant extracts or} constituents

Murralonginol

Micromelin

Scopoletin

Microminutin

Murrangatin

Minumicrolin

Clauslactone $\mathrm{E}$

Minutin B

Phebalosin

7-demethylmurralongino isovalerate

Murralonginol isovalerate

Minutin A

\section{Cytotoxicity}

- Exhibited cytotoxicity against cholangiocarcinoma cell line, KKU- 100 with IC50 value of $\mathrm{I} 0.0 \mu g / \mathrm{mL}$.

- Found to be weakly cytotoxic against human epidermoid $(\mathrm{KB})$ cell line with IC50 value of $17.8 \mu \mathrm{g} / \mathrm{mL}$.

Weakly cytotoxic against human small cell lung ( $\mathrm{NCl}-\mathrm{HI} 87)$ cell line with the IC50 value of $27.1 \mu g / \mathrm{mL}$.

-Weakly cytotoxic against MCF-7 cell line (human breast cancer cells) with the IC50 value of $8.2 \mu g / \mathrm{mL}$.

Exhibited cytotoxicity against cholangiocarcinoma cell line, KKU-I00 with IC50 value of $9.0 \mu \mathrm{g} / \mathrm{mL}$.

Exhibited cytotoxicity against cholangiocarcinoma cell line, KKU-I00 with IC50 value of $9.2 \mu \mathrm{g} / \mathrm{mL}$.

- Exhibited cytotoxicity against cholangiocarcinoma cell line, KKU- 100 with IC50 value of $19.2 \mu g / \mathrm{mL}$.

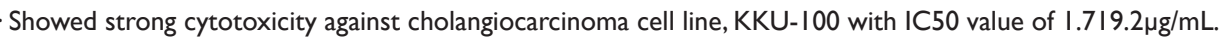

Showed strong cytotoxicity against cholangiocarcinoma cell line, KKU-I00 with IC50 value of $2.9 \mu g / \mathrm{mL}$.

- Exhibited cytotoxicity against cholangiocarcinoma cell line, KKU-I00 with IC50 value of $10.2 \mu g / \mathrm{mL}$.

- Possesses strong cytotoxic activity against the lung adenocarcinoma (SBC3 and A549) cell lines with IC50 values of $3.7 \mu \mathrm{M}$ and $10.4 \mu \mathrm{M}$ respectively.

- Possesses strong cytotoxic activity against the leukaemia (K562 and K562/ADM) cell lines with IC50 values of

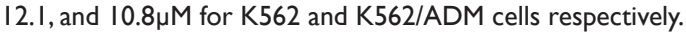

Showed a significant cytotoxic activity against Leishmania major with IC50 values of $9.8 \mu \mathrm{M}$.

- Possesses strong cytotoxic activity against the lung adenocarcinoma (SBC3 and A549) cell lines with IC50 values of $9.6 \mu \mathrm{M}$ and $17.5 \mu \mathrm{M}$ respectively.

Possesses strong cytotoxic activity against the leukaemia (K562 and K562/ADM) cell lines with IC50 values of 8.7 and $6.7 \mu \mathrm{M}$ for $\mathrm{K} 562$ and $\mathrm{K} 562 / \mathrm{ADM}$ cells respectively.

- Showed a significant cytotoxic activity against Leishmania major with IC50 values of $20.2 \mu \mathrm{M}$.

Significantly inhibitory on the development of crown gall tumors on potato discs $(\sim 64 \%$ and $\sim 70 \%$ in two independent determinations).

Significantly toxic to brine shrimp (IC50 47ppm, 95\% confidence interval 3I-69ppm)

Weakly cytotoxic against the human epidermoid (KB) cell line with IC50 value of $4 \mathrm{I} . \mathrm{I \mu g} / \mathrm{mL}$.

-Weakly cytotoxic against human small cell lung $(\mathrm{NCl}-\mathrm{HI} 87)$ cell line with the IC50 value of $46.5 \mu g / \mathrm{mL}$.

-Weakly cytotoxic against MCF-7 cell line (human breast cancer cells) with the IC50 value of $24.3 \mu \mathrm{g} / \mathrm{mL}$.

Weakly cytotoxic against the the human epidermoid (KB) cell line with IC50 value of $30.4 \mu \mathrm{g} / \mathrm{mL}$.

-Weakly cytotoxic against human small cell lung $(\mathrm{NCl}-\mathrm{HI} 87)$ cell line with the IC50 value of $49.5 \mu g / \mathrm{mL}$.

-Weakly cytotoxic against MCF-7 cell line (human breast cancer cells) with the IC50 value of $25.4 \mu \mathrm{g} / \mathrm{mL}$.

Showed a significant cytotoxic activity against Leishmania major with IC50 values of $26.2 \mu \mathrm{M}$. 


\section{Conclusion}

Micromelum minutum has a wide range of use in folk medicine. But most of the scientific studies have been done on the cytotoxicity of the plant because the plant is a rich source of that. This review compiled cytotoxic properties of all types of compounds found and investigated on, not only the coumarins. It also listed the chemical constituents and traditional uses of the plant. These will help researchers in following ways: to develop and design a drug based on cytotoxic properties found here; facilitate researchers who are finding a source for a particular compound and investigate on other properties of the plant constituents that are already found.

\section{Acknowledgments}

None.

\section{Conflicts of interest}

Authors declare that there is no conflict of interest.

\section{References}

1. https://www.britannica.com/plant/Rutaceae

2. Supabpho R, Tangjitjareonkun J. Chemical Constituents and Biological Activities of Zanthoxylum limonella (Rutaceae): A Review. Tropical Journal of Pharmaceutical Research. 2014;13 (12):2119-2130.

3. Lewis JR. Biological activity of some Rutaceous compounds. In: Waterman PG, Grundon MF, editors. Chemistry and Chemical Taxonomy of Rutales. London: Academic Press; 1983. 301-318 p

4. Ali MS, Fatima S, Pervez MK. Haplotin: A New Furanoquinoline from Haplophyllum acutifolium (Rutaceae). J Chem Soc Pak. 2008;30:775-779.

5. Mandal S, Nayak A, Kar M, et al. Antidiarrhoeal activity of carbazole alkaloids from Murraya koenigii Spreng (Rutaceae) seeds. Fitoterapia. 2010;81(1):72-74.

6. Cardoso-Lopes EM, Maier JA, Da Silva MR, et al. Alkaloids from stems of Esenbeckia leiocarpa Engl. (Rutaceae) as potential treatment for Alzheimer disease. Molecules. 2010;15(12):9205-9213.

7. Carlos Andres CA, Coy Barrera ED, Granados Falla DS, et al. secoLimonoids and quinoline alkaloids from Raputia heptaphylla and their antileishmanial activity. Chem Pharm Bull. 2011;59(7):855-859.

8. Rajkumar S, Jebanesan A. Bioactivity of flavonoid compounds from Poncirus trifoliate L. (Family: Rutaceae) against the dengue vector, Aedes aegypti L. (Diptera: Culicidae). Parasitol Res. 2008;104(1):19-25.

9. Emam AM, Swelam S, Megally NY. Furocoumarin and quinolone alkaloid with larvicidal and antifeedant activities isolated from Ruta chalepensis leaves. J Nat Prod. 2009;2:10-22.

10. Su JF, Guo CJ, Wei JY, et al. Protection against hepatic ischemia reperfusion injury in rats by oral pretreatment with quercetin. Biomed Environ Sci. 2003;16(1):1-8.

11. Swingle WT, rev. P. C. Reece. Chapter 3: The Botany of Citrus and its Wild Relatives. In: The Citrus Industry. vol 1. Webber HJ. (ed.). Berkeley: University of California Press; 1967.

12. Huang S, Wang JH, Luo XM, et al. Research process on chemical constituents and pharmacological activities of Micromelum. Chin J Med Mat. 2011;34(10):1635-1638.

13. Wang ZY, He WJ, Zhou WB. Two New Phenylpropanoids From Micromelum Integerrimum. Chin J Nat Med. 2014;12(8):619-622.
14. Khaled MM Koriem, Aminuddin ME, Kader AS, et al. Antihyperglycemic, Antihyperlipidemic and Antiapoptotic Activities of Micromelum minutum Seeds in Diabetic Rats. $J$ Mol Genet Med. 2013;S1:1-8.

15. Hyland BPM, Whiffin T, Zich FA, et al. (Dec 2010). FactsheetMicromelum minutum. Australian Tropical Rainforest Plants. Edition 6.1, online version [RFK 6.1]. Cairns, Australia: Commonwealth Scientific and Industrial Research Organisation (CSIRO), through its Division of Plant Industry; the Centre for Australian National Biodiversity Research; the Australian Tropical Herbarium, James Cook University; 2013.

16. Wiart, Christophe. Medicinal Plants of Asia and the. CRC Press; 2006. 223-224 p.

17. Cambie RC, Ash J. Fijian Medicinal Plants. CSIRO Publishing; 1994 2031-2032 p.

18. Croft KD, Toia RF. Coumarins from Micromelum minutum. Planta Med. 1989;55:401.

19. Itharat A, Houghton PJ, Eno-Amooquaye E. In vitro cytotoxic activity of Thai medicinal plants used traditionally to treat cancer. $J$ Ethnopharmacol. 2004;90(1):33-38.

20. Pongboonrod S. Mai Thed Muang Thai. Bangkok, Thailand: Kaseambunnakit Printing; 1950. 428-429 p. (in Thailand).

21. Ken Fern; Tropical Plants Database.

22. Ito $\mathrm{C}$, Otsuka $\mathrm{T}$, Ruangrungsi $\mathrm{N}$, et al. Chemical Constituents of Micromelum minutum. Isolation and Structural Elucidation of New Coumarins. Chem Pharm Bull. 2000;48(3):334-338.

23. Tan BK, Alitheen NB, Yeap SK, et al. Cytotoxic effect of 2', 3'-epoxy isocapnolactone and 8- hydroxyisocapnolactone-2'3'-diol isolated from Micromelum minutum (G.Forst.) Wight and Arn. in human T-lymphocyte leukemia CEM-SS cells. African Journal of Biotechnology. 2009;8(18):4632-4641.

24. Tantivatana P, Ruangrungsi N, Vaisiriroj V, et al. Microminutin, a novel cytotoxic coumarin from Micromelum minutum (Rutaceae). J Org Chem. 1983;48(2):268-270.

25. Sakunpak A, Matsunami K, Otsuka $\mathrm{H}$, et al. Isolation of new monoterpene coumarins from Micromelum minutum leaves and their cytotoxic activity against Leishmania major and cancer cells. Food Chem. 2013;139(1-4):458-63.

26. Lekphrom R, Kanokmedhakul K, Sangsopha W, et al. A new coumarin from the roots of Micromelum minutum. Natural Product Research. 2016;30(21):2383-2388.

27. Susidarti RA, Rahmani M, Hazar BM. Ismail, et al. Cytotoxic activity of coumarins from Micromelumminutum. Pharmaceutical Biology. 2009;47(2):182-185.

28. Tan BK, Alitheen NB, Yeap SK, et al. Cytotoxic effect of 2', 3'-epoxy isocapnolactone and 8- hydroxyisocapnolactone-2'3'-diol isolated from Micromelum minutum (G.Forst.) Wight and Arn. in human T-lymphocyte leukemia CEM-SS cells. African Journal of Biotechnology. 2009;8(18):4632-4641.

29. Roy MK, Thalang VN, Trakoontivakorn G, et al. Mahanine, a carbazole alkaloid from Micromelum minutum, inhibits cell growth and induces apoptosis in U937 cells through a mitochondrial dependent pathway. $\mathrm{Br}$ J Pharmacol. 2005;145(2):145-155.

30. Nakahara K, Trakoontivakorn G, Alzoreky NS, et al. Antimutagenicity of some edible thai plants, and a bioactive carbazole alkaloid, mahanine, isolated from micromelum minutum. J Agric Food Chem. 2002;50(17):4796-4802. 
31. Skehan P, Storeng R, Scudiero D, et al. New colorimetric cytotoxicity assay for anticancer-drug screening. J Natl Cancer Inst. 1990;82(13):1107-1112.

32. Croft KD, Toia RF. Coumarins from Micromelum minutum. Plante Med. 1989;55:401.

33. Sakunpak A, Matsunami $\mathrm{K}$, Otsuka $\mathrm{H}$, et al. Isolation of new monoterpene coumarins from Micromelum minutum leaves and their cytotoxic activity against Leishmania major and cancer cells. Food Chem. 2013;139(1-4):458-463.

34. Tantishaiyakul V, Pummangura S, Chaichantipyuth C, et al. Phebalosin from the Bark of Micromelum minutum. Nat Prod. 1986;49(1):180-181.

35. Lekphrom R, Kanokmedhakul S, Kukongviriyapan V, et al. C-7 Oxygenated Coumarins from the Fruits of Micromelum minutum. Arch Pharm Res. 2011;34(4):527-531.
36. Rahmani M, Susidarti RA, Ismail HBM, et al. Coumarins from Malaysian Micromelum minutum. Phytochemistry. 2003;64(4):873-877.

37. Rahmani M, Taufiq-Yap YH, Ismail HBM, et al. New coumarin and dihydrocinnamic acid derivatives from two Malaysian populations of Micromelum minutum. Phytochemistry. 1994;37(2):561-564.

38. Susidarti RA, Rahmani M, Ismail HBM, et al. A new coumarin and triterpenes from Malaysian Micromelum minutum. Nat Prod Res. 2006;20(2):145-151.

39. Skehan P, Storeng R, Scudiero D, et al. New colorimetric cytotoxicity assay for anticancer-drug screening. J Natl Cancer Inst. 1990;82(13):1107-1112. 